\title{
DISTURBANCES AS A STRUCTURING FACTOR OF PLANT PALATABILITY IN AQUATIC COMMUNITIES
}

\author{
Arnaud Elger, ${ }^{1}$ Gudrun Bornette, Marie-Hélène Barrat-Segretain, and Claude Amoros \\ UMR CNRS 5023, Ecology of Fluvial Hydrosystems, University of Lyon 1, 69622 Villeurbanne cedex, France
}

\begin{abstract}
Plant palatability plays an important part in the fitness of species and is therefore regarded as a key functional trait. The aim of this study was to relate the palatability of aquatic macrophytes to their distribution in riverine wetlands differing in their exposure to spate flood disturbances. Thirty-three former channels of the Rhône River Basin (eastern France) were characterized in terms of flood-disturbance level. Nutrient richness was also measured to eliminate its potential confounding effect. The coverage of 40 macrophyte species was recorded in these wetlands, and their palatability was assessed through laboratory feeding trials using a generalist consumer, the pond snail Lymnaea stagnalis. The consumption rate of L. stagnalis ranged from $3.9 \mathrm{mg} \cdot \mathrm{g}^{-1} \cdot \mathrm{d}^{-1}$ (for Hottonia palustris) to $137.9 \mathrm{mg} \cdot \mathrm{g}^{-1} \cdot \mathrm{d}^{-1}$ (for Sagittaria sagittifolia) and was used as a palatability index. Plant palatability was unrelated to the nutrient richness of sites but was positively correlated with their flood-disturbance level. However, the strength of this correlation decreased as nutrient richness increased. These results suggest that spate floods promote functional diversity in riverine wetlands, allowing the persistence of the most palatable plant species otherwise eliminated by herbivores, especially in nutrient-poor habitats.
\end{abstract}

Key words: disturbance; diversity, functional; fluvial dynamics; freshwater macrophytes; herbivory; Lymnaea stagnalis; nutrient richness; plant palatability; riverine wetlands; spate floods.

\section{INTRODUCTION}

Invertebrate herbivory plays an important part in the geographical distribution and relative abundance of plant species, both in terrestrial (Bruelheide and Scheidel 1999, Erneberg 1999), marine (Tamelen 1996, Duffy and Hay 2000) and freshwater systems (Lodge and Lorman 1987, Sheldon 1987). Plant palatability is regarded as a key functional trait, as it governs in part the competitive success of species (Van et al. 1998, Rachich and Reader 1999, Gross et al. 2001). Some plant species can effectively reduce herbivore consumption through morphological adaptations or deterrent chemical compounds (Newman et al. 1996, Cronin 1998, Pennings et al. 1998, Kubanek et al. 2001). Such species should have the ability to persist in habitats where herbivore pressure is high, even under resourcelimited conditions (Coley et al. 1985, Sheldon 1987). In contrast, high-palatability species should be restricted to habitats either with low herbivore pressure (Sheldon 1987, Feminella and Resh 1989, Tamelen 1996), or where productivity is sufficiently high to allow plants to compensate for biomass losses (Coley et al. 1985, Jacobsen and Sand-Jensen 1992).

Previous studies have demonstrated that the most palatable species are generally associated with early stages of secondary succession (Grime et al. 1968,

Manuscript received 6 December 2002; revised 20 June 2003; accepted 24 June 2003. Corresponding Editor: S. C. Pennings.

${ }^{1}$ Present address: Department of Plant-Animal Interactions, Netherlands Institute of Ecology (NIOO-KNAW), P.O. Box 1299, 3600 BG Maarssen, The Netherlands.

E-mail: a.elger@nioo.knaw.nl
Cates and Orians 1975, Briner and Frank 1998, Elger et al. 2002). Such species are typically fast growing, allocate a large part of their resources to reproduction, and are favored by both high disturbance levels and high nutrient availability (i.e., "ruderal" species, sensu Grime [2001] and Kautsky [1988]). Microcosm experiments demonstrated that ruderal species are the most affected by the presence of herbivores (Fraser and Grime 1999, Buckland and Grime 2000). However, as far as we know, no study has tested the link between the palatability of plant species and their relative abundance in natural communities distributed along a disturbance gradient.

Macrophyte communities in former channels of piedmont rivers are ideal systems for field testing the relationship between disturbance level and plant palatability. Such communities are spatially well delimited, and their species composition is strongly influenced by spate disturbances (Bornette et al. 1998, 2001). These scouring events are brief and unpredictable, and they break or uproot aquatic plants (Henry et al. 1994, 1996). The exposure of former channels to spate scouring depends on their location relative to the active channel and on other geomorphological properties such as their slope and sinuosity. These channels can therefore be ranked along a disturbance gradient.

The purpose of the present work is to determine if the palatability of freshwater macrophyte species is correlated with the disturbance level of their habitat. The hypothesis is that a positive correlation should occur between the palatability of the species and the disturbance levels of the sites where they are the most 
abundant. To avoid a potentially confounding effect of site nutrient richness, which might also be positively correlated with plant palatability (Coley et al. 1985) and could covary with site disturbance level (Bornette et al. 2001), we independently assessed nutrient richness in the wetlands studied, and tested the effect of these two environmental factors on plant palatability.

\section{Materials And Methods}

The study was undertaken in 33 former channels of the Rhône River Basin, in Eastern France $\left(45^{\circ} 82^{\prime} \mathrm{N}\right.$, $\left.5^{\circ} 20^{\prime} \mathrm{E}\right)$. Twenty-one of these wetlands were located along the Rhône River, and 12 along one of its tributaries, the Ain River.

\section{Assessment of the environmental characteristics of the study sites}

As the direct assessment of flow velocity is not possible during spate floods, disturbance level was assessed through site exposure to spate floods, and through observed effects of disturbance (substrate erosion). Site exposure was estimated through the annual number of days of river overflow in the former channel (each flood event does not exceed four days on average [Combroux et al. 2001]), channel slope, and drainage capacity (mean depth and width). Increasing slope or decreasing drainage capacity of the channel both increase flow velocity, i.e., the scouring effect of floods (Bravard and Gilvear 1996, Gilvear and Bravard 1996). As the Ain and Rhône Rivers differ in their discharge rates, the drainage capacity of the channels studied was normalized per river system to allow comparisons. The net effect of disturbances was assessed through substrate grain size, which provides information on the dominant process, either erosion or deposition, operating in the former channels of a given alluvial floodplain (Poff and Ward 1990, Lamberti et al. 1991). Substrate grain size was visually assessed on 2-m-wide transects crossing the channels and distributed regularly along their upstream-downstream gradient (one per 25 or $50 \mathrm{~m}$, depending on channel length and substrate heterogeneity). The percentage cover of each of the following five grain-size classes was recorded: coarse, diameter $(D)=2-250 \mathrm{~mm}$; sand or sandy silt, $D=0.01-2 \mathrm{~mm}$; silt and clay, $D<0.01 \mathrm{~mm}$; mud; and peat. Substrate grain-size profiles were then established for each channel (relative abundance of each grain-size class, summed abundance $=100 \%$ ). Normalized principal component analysis (nPCA) was performed on the grain-size table, and the first principal component was used as an integrative grain-size variable for the assessment of flood-disturbance level. The location of each channel $j$ along the disturbance gradient $\left(\mathrm{Dis}_{j}\right)$ was provided by the first principal component of a second nPCA performed on overflow frequency, slope, and normalized drainage capacity of the channel, together with the integrative grain-size variable.
Both phosphate and ammonium levels in the water have been recognized to be the main parameters governing nutrient status in aquatic habitats (Kohler et al. 1974, Carbiener et al. 1990). Water samples were collected monthly from each site over one year for chemical analysis. Ammonium $\mathrm{N}$ and phosphate contents were measured by colorimetry after standard $\mathrm{HACH}$ procedures (HACH Company, Loveland, Colorado, USA). As sediment is able to accumulate phosphorus and to act therefore as an alternative nutrient source for aquatic plants (House et al. 1998), total phosphorus content of the five upper centimeters of sediment was also measured by spectrophotometry on core samples collected at each site. The nutrient content of both water and substrate (water phosphate and ammonium $\mathrm{N}$ contents, total sediment phosphorus content) were analyzed through nPCA, and the first principal component was used to define the location of each channel $j$ along the nutrient gradient $\left(\mathrm{Nut}_{j}\right)$.

\section{Vegetation sampling}

Aquatic vegetation was surveyed on 2-m-wide transects crossing the former channels and distributed regularly along their upstream-downstream gradient (one per 25 or $50 \mathrm{~m}$, depending on channel length and spatial heterogeneity, resulting in 4 to 64 transects per channel). The cover of each occurring species was visually measured and expressed as the relative cover percentage of the species on the transect, using the BraunBlanquet cover classes (Braun-Blanquet 1932). The average cover percentage of each species was then calculated for each channel.

\section{Assessment of plant palatability}

The palatability of 40 macrophyte species was assessed with the pond snail Lymnaea stagnalis (L.), which has been successfully used in previous similar laboratory studies (Smits 1994, Elger et al. 2002). The regular diet of this snail includes both decaying and living macrophyte materials, microbenthic algae, and dead animals (Reavell 1980). Contrary to most freshwater gastropod species, L. stagnalis presents several attributes indicating that it is adapted to macrophyte feeding. Its big size $(30-50 \mathrm{~mm}$ shell length on average) allows it to ingest coarse fragments of food, and its digestion of tough cell walls is facilitated by an active ingestion of mineral particles and by an endogenous cellulase activity, higher than for most other freshwater gastropod species (Carriker 1946, Calow and Calow 1975). Lymnaea stagnalis has been shown to graze readily on more than 30 macrophyte species among 15 families (Frömming 1956, Gaevskaya 1969, Smits 1994), and can therefore be considered as a generalist consumer.

Lymnaea stagnalis individuals were grown on a lettuce-based diet in aquaria, in filtered water kept close to $22^{\circ} \mathrm{C}$, and were used in palatability experiments $12-$ 18 weeks after hatching (shell length: $30.5 \pm 1.7 \mathrm{~mm}$

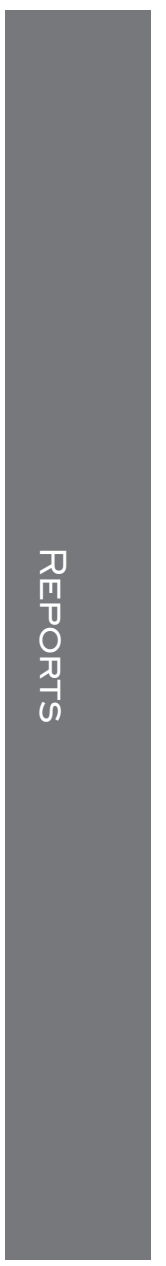


TABLE 1. Macrophyte species investigated for palatability in laboratory experiments using the pond snail Lymnaea stagnalis (L.).

\begin{tabular}{|c|c|c|c|c|}
\hline Family & Species & Type of fragments & $n \dagger$ & $N \ddagger$ \\
\hline Characeae & $\begin{array}{l}\text { Chara major Vaillant } \\
\text { Chara vulgaris L. }\end{array}$ & $\begin{array}{l}\text { leaves } \\
\text { shoots }\end{array}$ & $\begin{array}{r}15 \\
7\end{array}$ & $\begin{array}{l}2 \\
1\end{array}$ \\
\hline Nymphaeaceae & $\begin{array}{l}\text { Nuphar lutea }(\mathrm{L} .) \text { Smith } \\
\text { Nymphaea alba } \mathrm{L} .\end{array}$ & $\begin{array}{l}\text { portions of leaves } \\
\text { portions of leaves }\end{array}$ & $\begin{array}{l}13 \\
15\end{array}$ & $\begin{array}{l}1 \\
2\end{array}$ \\
\hline Ceratophyllaceae & Ceratophyllum demersum $\mathrm{L}$. & shoots & 15 & 1 \\
\hline Alismataceae & $\begin{array}{l}\text { Baldellia ranunculoides (L.) Parl. } \\
\text { Luronium natans (L.) Rafin. } \\
\text { Sagittaria sagittifolia L. }\end{array}$ & $\begin{array}{l}\text { portions of leaves } \\
\text { portions of leaves } \\
\text { portions of leaves }\end{array}$ & $\begin{array}{l}15 \\
15 \\
15\end{array}$ & $\begin{array}{l}1 \\
1 \\
2\end{array}$ \\
\hline Lemnaceae & $\begin{array}{l}\text { Lemna minor } \mathrm{L} . \\
\text { Lemna trisulca } \mathrm{L} .\end{array}$ & $\begin{array}{l}\text { whole plant } \\
\text { whole plant }\end{array}$ & $\begin{array}{l}15 \\
15\end{array}$ & $\begin{array}{l}3 \\
1\end{array}$ \\
\hline Hydrocharitaceae & $\begin{array}{l}\text { Elodea canadensis Michaux } \\
\text { Elodea nuttallii (Planchon) H. St John } \\
\text { Hydrocharis morsus-ranae L. }\end{array}$ & $\begin{array}{l}\text { shoots } \\
\text { shoots } \\
\text { leaves }\end{array}$ & $\begin{array}{l}15 \\
14 \\
15\end{array}$ & $\begin{array}{l}2 \\
2 \\
2\end{array}$ \\
\hline Najadaceae & Najas marina $\mathrm{L}$ & shoots & 14 & 1 \\
\hline Potamogetonaceae & $\begin{array}{l}\text { Groenlandia densa (L.) Fourr. } \\
\text { Potamogeton coloratus Hornem. } \\
\text { Potamogeton compressus L. } \\
\text { Potamogeton crispus L. } \\
\text { Potamogeton lucens L. } \\
\text { Potamogeton natans L. } \\
\text { Potamogeton nodosus Poiret } \\
\text { Potamogeton pectinatus L. } \\
\text { Potamogeton perfoliatus L. } \\
\text { Potamogeton pusilus L. }\end{array}$ & $\begin{array}{l}\text { shoots } \\
\text { portions of leaves } \\
\text { shoots } \\
\text { leaves } \\
\text { portions of leaves } \\
\text { portions of leaves } \\
\text { portions of leaves } \\
\text { leaves } \\
\text { leaves } \\
\text { shoots }\end{array}$ & $\begin{array}{l}15 \\
15 \\
15 \\
15 \\
15 \\
15 \\
15 \\
15 \\
15 \\
15\end{array}$ & $\begin{array}{l}3 \\
1 \\
1 \\
1 \\
2 \\
3 \\
2 \\
3 \\
2 \\
2\end{array}$ \\
\hline Cyperaceae & $\begin{array}{l}\text { Eleocharis acicularis (L.) Roem. \& Schult. } \\
\text { Scirpus lacustris L. }\end{array}$ & $\begin{array}{l}\text { portions of leaves } \\
\text { portions of leaves }\end{array}$ & $\begin{array}{l}15 \\
15\end{array}$ & $\begin{array}{l}2 \\
2\end{array}$ \\
\hline Juncaceae & Juncus articulatus L. & portions of leaves & 15 & 3 \\
\hline Sparganiaceae & Sparganium emersum Rehmann & portions of leaves & 13 & 3 \\
\hline Ranunculaceae & Ranunculus circinatus Sibth. & shoots & 15 & 2 \\
\hline Haloragaceae & Myriophyllum verticillatum L. & whorls of leaves & 15 & 2 \\
\hline Onagraceae & Ludwigia palustris (L.) Elliott & leaves & 15 & 2 \\
\hline Primulaceae & $\begin{array}{l}\text { Hottonia palustris } \mathrm{L} . \\
\text { Samolus valerandi } \mathrm{L} .\end{array}$ & $\begin{array}{l}\text { leaves } \\
\text { leaves }\end{array}$ & $\begin{array}{l}15 \\
14\end{array}$ & $\begin{array}{l}2 \\
2\end{array}$ \\
\hline Boraginaceae & Myosotis scorpioides L. & leaves & 15 & 3 \\
\hline Rubiaceae & Galium palustre $\mathrm{L}$. & shoots & 15 & 2 \\
\hline Lamiaceae & Mentha aquatica L. & leaves & 15 & 2 \\
\hline Lentibulariaceae & Utricularia vulgaris L. & shoots & 15 & 1 \\
\hline Callitrichaceae & Callitriche platycarpa Kütz. & shoots & 14 & 2 \\
\hline Hippuridaceae & Hippuris vulgaris L. & whorls of leaves & 15 & 2 \\
\hline Apiaceae & Berula erecta (Hudson) Coville & leaves & 15 & 2 \\
\hline
\end{tabular}

Note: Nomenclature follows Corillion (1975) for Characeae and Tutin et al. (1964-1980) for flowering species.

$\dagger$ Total number of replicates.

\$ Number of populations surveyed.

[mean $\pm 1 \mathrm{SD}])$. Plants were collected in the field, and samples were stored in a greenhouse for up to five days, in dechlorinated tap water aerated and kept below $18^{\circ} \mathrm{C}$. The different plant species were presented individually to L. stagnalis in a non-choice feeding experiment, to assess their relative palatability through snail feeding rate (Briner and Frank 1998, Wardle et al. 1998). A comparison of the feeding rates of L. stagnalis in nonchoice and multiple-choice experiments has shown that the ranking of macrophyte species was not significantly affected by the possibility of choice, which indicates that non-choice tests are prone to correctly order the species in terms of palatability and are little influenced by compensatory feeding (Elger et al. 2002).

The consumption of L. stagnalis was recorded on fragments of each plant species and expressed in terms of dry mass following the method described in Elger and Willby (2003). The types of fragment used for each plant species are indicated in Table 1. In the case of species that develop floating (e.g., Nuphar lutea, Potamogeton natans) or emergent leaves (e.g., Scirpus lacustris, Berula erecta), only submersed leaves were 
used. A relative consumption rate (RCR) was then calculated by dividing the consumption value by the body dry mass of the snail, estimated from its shell length using an allometric model previously described (Elger and Barrat-Segretain 2002).

Palatability experiments took place from the end of May to mid-July 2000. Every week, 4-8 plant species were tested, following a randomly determined order. When possible, plant species were each collected from two or three different sites to include intraspecific palatability variations in the analysis, and therefore calculate a mean RCR value that is representative of the study area. The number of sites investigated and the total number of replicates are given for each species in Table 1.

\section{Relationship between plant palatability and environmental factors}

We looked for a relationship between mean RCR, used as a palatability index of each plant species, and environmental characteristics of its habitat. The average locations of each species $i$ along the disturbance (Dis $s_{i}$ ) and nutrient $\left(\mathrm{Nut}_{i}\right)$ gradients were assessed on the basis of species cover in each channel $j\left(\operatorname{Cov}_{i j}\right)$ :

$$
\begin{aligned}
\operatorname{Dis}_{i}= & \frac{\sum_{j}\left(\operatorname{Cov}_{i j} \times \operatorname{Dis}_{j}\right)}{\sum_{j} \operatorname{Cov}_{i j}} \\
\operatorname{Nut}_{i}= & \frac{\sum_{j}\left(\operatorname{Cov}_{i j} \times \mathrm{Nut}_{j}\right)}{\sum_{j} \operatorname{Cov}_{i j}} .
\end{aligned}
$$

The interactive effects of $\mathrm{Nut}_{i}$ and $\mathrm{Dis}_{i}$ on $\mathrm{RCR}_{i}$ were assessed by means of multiple-regression analysis.

\section{RESUlts}

\section{Environmental characteristics of the study sites}

The first principal component of the analysis performed on the grain-size table explained $36 \%$ of its variation, and was positively correlated with silt/clay, sand, and coarse gravel ( $r=0.82,0.67$, and 0.16 , respectively), and negatively correlated with mud and peat $(r=-0.61$ and -0.52 , respectively). This principal component therefore expressed the intensity of erosive processes, which validated its use in assessing disturbance level. The first principal component of the analysis performed on the disturbance table explained $41 \%$ of its variation, and was positively correlated with substrate grain size, overflow frequency, and slope ( $r$ $=0.87,0.73$, and 0.41 , respectively), and negatively correlated with normalized drainage capacity $(r=$ -0.44). Hence, this component provided the location of the study sites along the disturbance gradient. The first principal component of the analysis performed on the nutrient-richness table explained $62 \%$ of its variation, and was positively correlated with both ammonium $\mathrm{N}$ water content, phosphate water content, and phosphorus sediment content $(r=0.91,0.88$, and 0.51 , respectively). Hence, this component provided the location of the study sites along the nutrient gradient. The locations of the study sites along nutrient and disturbance gradients were not significantly correlated ( $r$ $=0.11, n=33$ sites, $P=0.53$ ).

\section{Plant palatability}

The relative consumption rates recorded with Lymnaea stagnalis for the 40 plant species ranged from 3.9 $\pm 1.2 \mathrm{mg} \cdot \mathrm{g}^{-1} \cdot \mathrm{d}^{-1}$ (mean $\pm 1 \mathrm{SE}$ ) for Hottonia palustris, to $137.9 \pm 9.9 \mathrm{mg} \cdot \mathrm{g}^{-1} \cdot \mathrm{d}^{-1}$ for Sagittaria sagittifolia (Fig. 1). Interspecific differences in plant palatability were highly significant (ANOVA, $F_{39,544}=17.47, P<$ 0.001).

\section{Link between plant palatability and environmental factors}

The palatability of each plant species was positively correlated with the disturbance level of its habitat, but unrelated to its nutrient richness (Fig. 2A). When tested sequentially after the effect of nutrient richness in multiple-regression analysis, the effect of disturbance level on plant palatability increased in significance (Table 2). Plant palatability was also significantly influenced by the interactive effect of nutrient richness and disturbance level (Table 2). Indeed, the slope of the linear relationship between relative consumption rate RCR and species location along the disturbance gradient was maximal in the most oligotrophic sites and decreased as nutrient richness increased (Fig. 2B). The interactive effects of site nutrient richness and disturbance level accounted for $31.7 \%$ of the interspecific variability in plant palatability.

\section{Discussion}

As reported in previous studies (Chambers et al. 1991, Jacobsen 1994, Cronin 1998, Elger et al. 2002), our results revealed a wide interspecific variability in the palatability of freshwater macrophytes to a generalist invertebrate consumer. This trait is usually considered to depend primarily on plant morphology and on structural or chemical defenses, whereas the nutritive value of tissue would be of secondary importance (Chambers et al. 1991, Newman et al. 1996, Bolser et al. 1998, Lodge et al. 1998). However, the aim of the present work was not to identify the proximate causes of variation in plant palatability, but to focus on the ultimate causes of its variation. We therefore considered palatability as a global trait of each plant species, and attempted to relate it to environmental characteristics of its habitat.

We demonstrated a significant positive correlation between the palatability of macrophyte species and the disturbance level of their habitat, even when the effect of disturbance level was tested sequentially following that of nutrient richness in variance analysis. Jacobsen and Sand-Jensen (1995) showed that biomass losses 


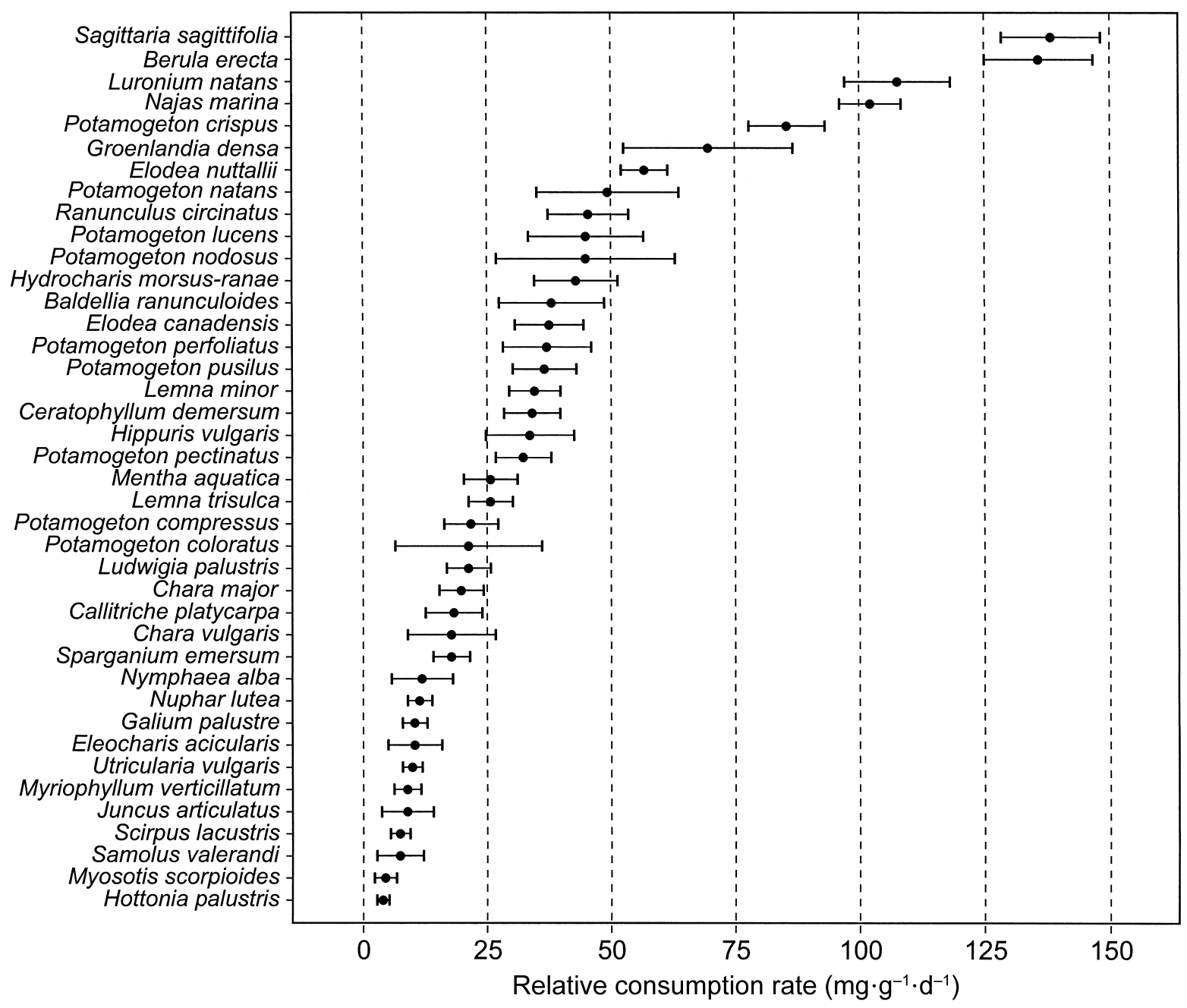

FIG. 1. Relative consumption rates recorded with Lymnaea stagnalis for 40 plant species through non-choice feeding experiments performed in the laboratory. Data are means $\pm 1 \mathrm{SE}$.

due to herbivory on Potamogeton perfoliatus in Danish streams and lakes were positively correlated with the biomass of some invertebrate grazers, especially Limnephilidae larvae, gastropods, and amphipods. The role of hydraulic disturbances (e.g., wave action in lakes or flood scouring in rivers) in the decrease of invertebrate biomass, especially herbivorous species, has been previously demonstrated (McGaha 1952, Newman 1991, Holomuzki and Biggs 1999, Nyström and McIntosh 2003). Therefore, high-palatability species should grow preferentially in disturbed sites, characterized by a low herbivore pressure. In contrast, high-palatability species are probably eliminated from stable habitats, likely because their susceptibility to grazing reduces their competitive ability (Van et al. 1998, Gross et al. 2001). This process of competitive exclusion does not explain why unpalatable species are less abundant in disturbed sites compared to others, but this pattern may be explained by the direct and ecological costs of anti-her- bivore defenses (Strauss et al. 2002). Actually, the synthesis of such defenses may be incompatible with the short development time and high reproductive investment required for the long-term persistence of plants in disturbed habitats (Kautsky 1988, Grime 2001).

We did not find any relation between the palatability of macrophyte species and the nutrient richness of their habitat. This is consistent with previous results from wetland habitats showing that the defensive investment of emergent macrophytes is unrelated to their location along a fertility gradient (McCanny et al. 1990). However, our data indicate that the positive correlation between plant palatability and disturbance level decreases as nutrient richness increases, the different species tending to have an intermediate palatability in nutrientrich habitats whatever the disturbance level. Invertebrate herbivory on macrophytes might be reduced in nutrient-rich habitats, even under low-disturbance regimes, due to the top-down effect of some predators 

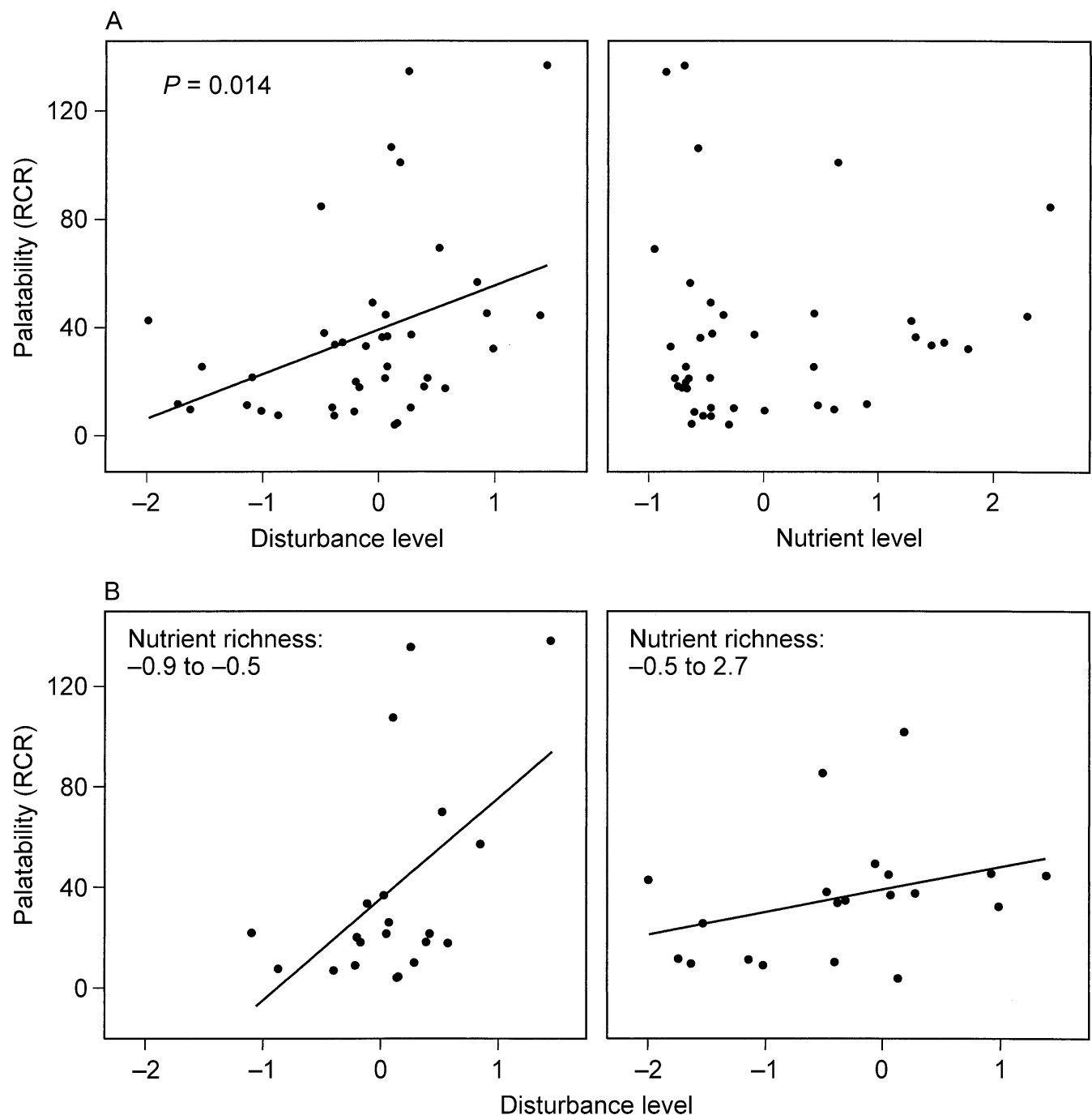

FIG. 2. Mean relative consumption rates (RCR) recorded with Lymnaea stagnalis for each of 40 plant species, used as a palatability index. (A) RCR plotted against species locations along the disturbance (left) and nutrient-richness (right) gradients. (B) RCR plotted against species locations along the disturbance gradient, for species located in nutrient-poor habitats (left) or in nutrient-rich habitats (right). This plot illustrates the interactive effect of disturbance level and nutrient richness on plant palatability, the slope of the linear relation between disturbance level and consumption rate decreasing as nutrient richness increases.

such as fish (Sheldon 1987), or due to the higher availability of alternative foods such as microbenthic algae (Sand-Jensen and Madsen 1989). Moreover, the ability of macrophytes to compensate for biomass losses is obviously higher in nutrient-rich habitats (Jacobsen and Sand-Jensen 1992). Species with intermediate palatabilities can therefore develop in undisturbed nutrientrich sites, thereby weakening the correlation between

TABLE 2. Variance analysis of the multiple regression between the mean relative consumption rate (RCR) calculated for each macrophyte species and its location along nutrient-richness and disturbance gradients.

\begin{tabular}{lrrrcc}
\hline \hline \multicolumn{1}{c}{ Parameter } & df & \multicolumn{1}{c}{ ss } & \multicolumn{1}{c}{ MS } & \multicolumn{1}{c}{$F$} & $P$ \\
\hline Nutrient richness & 1 & 123.1 & 123.1 & 0.15 & 0.7051 \\
Disturbance level & 1 & 7057.4 & 7057.4 & 8.34 & 0.0065 \\
Nutrient richness $\times$ disturbance level & 1 & 6951.5 & 6951.5 & 8.22 & 0.0069 \\
Residuals & 36 & 30447.3 & 845.8 & $\cdots$ & $\cdots$ \\
Total & 39 & 44887.2 & $\cdots$ & $\cdots$ & $\cdots$ \\
\hline
\end{tabular}


plant palatability and habitat disturbance level. The intermediate palatabilities of some species growing in disturbed habitats are more surprising, and the explanation of this pattern would require further investigations to determine the proximate factors involved in this decrease of palatability compared to species growing in disturbed nutrient-poor habitats.

The present work, combining field investigation and laboratory experiments, outlines the importance of spatial variation of flood disturbance in promoting plant diversity in fluvial corridors. Such variations in disturbance patterns may not only increase species richness on the floodplain scale (Pollock et al. 1998, Bornette et al. 2001), but may also promote functional diversity in riverine ecosystems, since low-palatability macrophyte species dominate stable communities, whereas high-palatability species tend to be eliminated from such communities, especially in nutrient-poor habitats. Although the exact role of herbivory in the exclusion of these species remains to be studied, perhaps via microcosm experiments or field manipulation, it is clear that palatable species are dependent on flood disturbances for their long-term persistence in fluvial corridors.

\section{ACKNOWLEDGMENTS}

We are grateful to Daniel Chessel for his valuable advice on statistical analysis. We also thank Christophe Henry, Sarah Malleval, Dominique Reynaud, and Alexandre Saint Olive for their field and laboratory assistance, and Patricia Hulmes for correcting the English text. The manuscript was greatly improved by comments from Steven C. Pennings and two anonymous reviewers.

\section{Literature Cited}

Bolser, R. C., M. E. Hay, N. Lindquist, W. Fenical, and D. Wilson. 1998. Chemical defenses of freshwater macrophytes against crayfish herbivory. Journal of Chemical Ecology 24:1639-1658.

Bornette, G., C. Amoros, H. Piegay, J. Tachet, and T. Hein. 1998. Ecological complexity of wetlands within a river landscape. Biological Conservation 85:35-45.

Bornette, G., H. Piegay, A. Citterio, C. Amoros, and V. Godreau. 2001. Aquatic plant diversity in four river floodplains: a comparison at two hierarchical levels. Biodiversity and Conservation 10:1683-1701.

Braun-Blanquet, J. 1932. Plant sociology: the study of plant communities. McGraw-Hill, New York, New York, USA.

Bravard, J. P., and D. J. Gilvear. 1996. Hydrological and geomorphological structure of hydrosystems. Pages 98116 in G. Petts and C. Amoros, editors. Fluvial Hydrosystems. Chapman and Hall, London, UK.

Briner, T., and T. Frank. 1998. The palatability of 78 wildflower strip plants to the slug Arion lusitanicus. Annals of Applied Biology 133:123-133.

Bruelheide, H., and U. Scheidel. 1999. Slug herbivory as a limiting factor for the geographical range of Arnica montana. Journal of Ecology 87:839-848.

Buckland, S. M., and J. P. Grime. 2000. The effects of trophic structure and soil fertility on the assembly of plant communities: a microcosm experiment. Oikos 91:336-352.

Calow, P., and L. J. Calow. 1975. Cellulase activity and niche separation in freshwater gastropods. Nature 255:478-480.

Carbiener, R., M. Trémolières, J. L. Mercier, and A. Ortscheit. 1990. Aquatic macrophyte communities as bioindicators of eutrophication in calcareous oligosaprobe stream waters (Upper Rhine plain, Alsace). Vegetatio 86:71-88.

Carriker, M. R. 1946. Observations on the functioning of the alimentary system of the snail Lymnaea stagnalis appressa Say. Biological Bulletin of Woods Hole 91:88-111.

Cates, R. G., and G. H. Orians. 1975. Successional status and the palatability of plants to generalized herbivores. Ecology 56:410-418.

Chambers, P. A., J. M. Hanson, and E. E. Prepas. 1991. The effect of aquatic plant chemistry and morphology on feeding selectivity by the crayfish Orconectes virilis. Freshwater Biology 25:339-348.

Coley, P. D., J. P. Bryant, and F. S. Chapin III. 1985. Resource availability and plant antiherbivore defense. Science $\mathbf{2 3 0}$ : 895-899.

Combroux, I., G. Bornette, N. J. Willby, and C. Amoros. 2001. Regenerative strategies of aquatic plants in disturbed habitats: the role of the propagule bank. Archiv für Hydrobiologie 152:215-235.

Corillion, R. 1975. Flore et végétation du massif armoricain: tome IV. Flore des Charophytes (Characées) du massif armoricain et des contrées voisines d'Europe occidentale. Jouve Editeurs, Paris, France.

Cronin, G. 1998. Influence of macrophyte structure, nutritive value, and chemistry on the feeding choices of a generalist crayfish. Pages 307-317 in E. Jeppesen, Ma. Søndergaard, Mo. Søndergaard, and K. Christoffersen, editors. The structuring role of submerged macrophytes in lakes. SpringerVerlag, New York, New York, USA.

Duffy, J. E., and M. E. Hay. 2000. Strong impacts of grazing amphipods on the organization of a benthic community. Ecological Monographs 70:237-263.

Elger, A., and M. H. Barrat-Segretain. 2002. Use of the pond snail Lymnaea stagnalis (L.) in laboratory experiments for evaluating macrophyte palatability. Archiv für Hydrobiologie 153:669-683.

Elger, A., M. H. Barrat-Segretain, and C. Amoros. 2002. Plant palatability and disturbance level in aquatic habitats an experimental approach using the snail Lymnaea stagnalis (L.). Freshwater Biology 47:931-940.

Elger, A., and N. J. Willby. 2003. Leaf dry matter content as an integrative expression of plant palatability: the case of freshwater macrophytes. Functional Ecology 17:58-65.

Erneberg, M. 1999. Effects of herbivory and competition on an introduced plant in decline. Oecologia 118:203-209.

Feminella, J. W., and V. H. Resh. 1989. Submersed macrophytes and grazing crayfish: an experimental study of herbivory in a California freshwater marsh. Holarctic Ecology 12:1-8.

Fraser, L. H., and J. P. Grime. 1999. Interacting effects of herbivory and fertility on a synthesized plant community. Journal of Ecology 87:514-525.

Frömming, E. 1956. Biologie der mitteleuropäischen Süsswasserschnecken. Duncker and Humblot, Berlin, Germany.

Gaevskaya, N. S. 1969. The role of higher aquatic plants in the nutrition of the animals of freshwater basins. (Translated from Russia by D. G. M. Muller, ed. K. H. Mann). Volumes I-III. National Lending Library of Science and Technology, Yorkshire, UK.

Gilvear, D. J., and J. P. Bravard. 1996. Geomorphology of temperate rivers. Pages 68-97 in G. Petts and C. Amoros, editors. Fluvial hydrosystems. Chapman and Hall, London, UK.

Grime, J. P. 2001. Plant strategies, vegetation processes, and ecosystem properties. John Wiley and Sons, Chichester, UK

Grime, J. P., S. F. MacPherson-Stewart, and R. S. Dearman. 1968. An investigation of leaf palatability using the snail Cepaea nemoralis L. Journal of Ecology 56:405-420. 
Gross, E. M., R. L. Johnson, and N. G. Hairston, Jr. 2001. Experimental evidence for changes in submersed macrophyte species composition caused by the herbivore Acentria ephemerella (Lepidoptera). Oecologia 127:105-114.

Henry, C. P., C. Amoros, and G. Bornette. 1996. Species traits and recolonization processes after flood disturbances in riverine macrophytes. Vegetatio 122:13-27.

Henry, C. P., G. Bornette, and C. Amoros. 1994. Differential effects of floods on the aquatic vegetation of braided channels of the Rhône River. Journal of the North American Benthological Society 13:439-467.

Holomuzki, J. R., and B. J. F. Biggs. 1999. Distributional responses to flow disturbance by a stream-dwelling snail. Oikos 87:36-47.

House, W. A., T. D. Jickell, A. C. Edwards, K. E. Praska, and F. H. Denison. 1998. Reactions of phosphorus with sediments. Soil Use and Management 14:147-153.

Jacobsen, D. 1994. Food preference of the caddis larva Anabolia nervosa feeding on aquatic macrophytes. Internationale Vereinigung für Theoretische und Angewandte Limnologie, Verhandlungen 25:2478-2481.

Jacobsen, D., and K. Sand-Jensen. 1992. Herbivory of invertebrates on submerged macrophytes from Danish freshwaters. Freshwater Biology 28:301-308.

Jacobsen, D., and K. Sand-Jensen. 1995. Variability of invertebrate herbivory on the submerged macrophyte Potamogeton perfoliatus. Freshwater Biology 34:357-365.

Kautsky, L. 1988. Life strategies of aquatic soft bottom macrophytes. Oikos 53:126-135.

Kohler, A., R. Brinkmeier, and H. Vollrath. 1974. Verbreitung und Indikatorwert der submersen Makrophyten in den Fließgewässern der Friedberger Au. Bericht der Bayerischen Botanischen Gesellschaft zür Erforschung der Heimischen Flora 45:5-36.

Kubanek, J., M. E. Hay, P. J. Brown, N. Lindquist, and W. Fenical. 2001. Lignoid chemical defenses in the freshwater macrophyte Saururus cernuus. Chemoecology 11:1-8.

Lamberti, G. A., S. V. Gregory, L. R. Ashkenas, R. C. Wildman, and K. M. S. Moore. 1991. Stream water-body recovery following a catastrophic debris flow. Canadian Journal of Fisheries and Aquatic Sciences 48:196-207.

Lodge, D. M., G. Cronin, E. van Donk, and A. J. Froelich. 1998. Impact of herbivory on plant standing crop: comparisons among biomes, between vascular and nonvascular plants, and among freshwater herbivore taxa. Pages 149174 in E. Jeppesen, Ma. Søndergaard, Mo. Søndergaard, and K. Christoffersen, editors. The structuring role of submerged macrophytes in lakes. Springer-Verlag, New York, New York, USA.

Lodge, D. M., and J. G. Lorman. 1987. Reductions in submersed macrophyte biomass and species richness by the crayfish Orconectes rusticus. Canadian Journal of Fisheries and Aquatic Sciences 44:591-597.

McCanny, S. J., P. A. Keddy, T. J. Arnason, C. L. Gaudet, D. R. J. Moore, and B. Shipley. 1990. Fertility and the food quality of wetland plants: a test of the resource availability hypothesis. Oikos 59:373-381.
McGaha, Y. J. 1952. The limnological relations of insects to certain aquatic flowering plants. Transactions of the American Microscopical Society 71:355-381.

Newman, R. M. 1991. Herbivory and detritivory on freshwater macrophytes by invertebrates: a review. Journal of the North American Benthological Society 10:89-114.

Newman, R. M., W. C. Kerfoot, and Z. Hanscom. 1996. Watercress allelochemical defends high-nitrogen foliage against consumption: effects on freshwater invertebrate herbivores. Ecology 77:2312-2323.

Nyström, P., and A. R. McIntosh. 2003. Are impacts of an exotic predator on a stream food web influenced by disturbance history? Oecologia 136:279-288.

Pennings, S. C., T. H. Carefoot, E. L. Siska, M. E. Chase, and T. A. Page. 1998. Feeding preferences of a generalist salt-marsh crab: relative importance of multiple plant traits. Ecology 79:1968-1979.

Poff, L. N., and J. V. Ward. 1990. Physical habitat template of lotic systems: recovery in the context of historical pattern of spatiotemporal heterogeneity. Environmental Management 14:629-645.

Pollock, M. M., R. J. Naiman, and T. A. Hanley. 1998. Plant species richness in riparian wetlands-a test of biodiversity theory. Ecology 79:94-105.

Rachich, J., and R. Reader. 1999. Interactive effects of herbivory and competition on blue vervain (Verbena hastata L.: Verbenaceae). Wetlands 19:156-161.

Reavell, P. E. 1980. A study of the diets of some British freshwater gastropods. Journal of Conchology 30:253-271.

Sand-Jensen, K., and T. V. Madsen. 1989. Invertebrates graze submerged rooted macrophytes in lowland streams. Oikos 55:420-423.

Sheldon, S. P. 1987. The effects of herbivorous snails on submerged macrophyte communities in Minnesota lakes. Ecology 68:1920-1931.

Smits, A. J. M. 1994. Ecophysiological studies on nymphaeid water plants. Dissertation. University of Nijmegen, Nijmegen, The Netherlands.

Strauss, S. Y., J. A. Rudgers, J. A. Lau, and R. E. Irwin. 2002. Direct and ecological costs of resistance to herbivory. Trends in Ecology and Evolution 17:278-285.

Tamelen, P. G. 1996. Algal zonation in tidepools: experimental evaluation of the roles of physical disturbance, herbivory and competition. Journal of Experimental Marine Biology and Ecology 201:197-231.

Tutin, E. D., V. H. Heywood, N. A. Burges, D. H. Valentine, S. M. Walters, and D. A. Webb. 1964-1980. Flora Europaea. Volumes 1-5. Cambridge University Press, Cambridge, UK.

Van, T. K., G. S. Wheeler, and T. D. Center. 1998. Competitive interactions between Hydrilla (Hydrilla verticillata) and Vallisneria (Vallisneria americana) as influenced by insect herbivory. Biological Control 11:185-192.

Wardle, D. A., G. M. Barker, K. I. Bonner, and K. S. Nicholson. 1998. Can comparative approaches based on plant ecophysiological traits predict the nature of biotic interactions and individual plant species effects in ecosystems? Journal of Ecology 86:405-420.

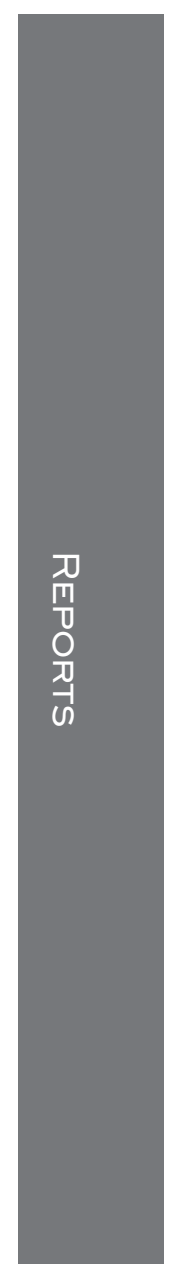

